\title{
Penipuan dengan Menggunakan Telepon Seluler Ditinjau dari KUHP
}

\author{
Theodorus Rumampuk
}

Nowadays the development of technology in telecommunication becomes more sophisticated. In this connection it has been seen the tool of communication that is cellular phone. The function of this phone can be able to help human to communicate the message to other people in the distant location. But the negative impact of this phone for instance deception by short message service. In this sense, the problem is the deception could be classified as a criminal according to KUHP. According to the writer this kind of deception could be classified criminal act based on article 378-395 of KUHP.

Kata Kunci: aspek hukum, penipuan, dan teknologi seluler

$\mathrm{D}$ ewasa ini teknologi di bidang telekomunikasi semakin berkembang dengan pesat. Hal ini dapat kita lihat dengan adanya sarana komunikasi berupa telepon seluler yang berfungsi untuk membantu manusia menyampaikan pesan kepada orang lain yang berada jauh dari tempatnya tanpa harus mencari fasilitas telepon tetap (fixed line). Telepon seluler atau biasa disingkat ponsel biasa disebut sebagai telepon mobil nirkabel (tanpa kabel), wireless mobile phone, wireless HP. Telepon jenis ini dihubungkan dengan radio dalam suatu jaringan, dan oleh karena itu disebut telepon mobil nirkabel, karena dapat berpindah dengan mudah tanpa terjadi putusnya komunikasi. Sebagai catatan, demi kelancaran tulisan ini, mobile diartikan sebagai perpindahan yang mudah dari satu tempat ke tempat yang lain. Sedangkan telepon tetap kabel adalah sebutan untuk terminal telepon yang terhubung dengan kabel, dan oleh karena itu tidak bisa berpindah dan harus tetap bergantung pada lokasi telepon ini dipasang ( Silalahi, 2002).

Dari rumusan pengertian di atas menunjukkan bahwa telepon seluler ini sangat praktis untuk digunakan dalam melakukan komunikasi dimana saja kita berada. Di lain pihak kehadiran media telepon seluler ini bermanfaat dalam rangka penggunaan waktu yang efisien, tanpa harus membuang waktu untuk menemukan fasilitas telepon tetap (fixed line) di tempat lain.

Heru Sutadi telah menulis dalam surat kabar Sinar Harapan tanggal 7 September 2002,bahwa:"Mencermati perkembangan dunia telekomunikasi di Indonesia, salah satu fenomena yang menarik untuk diamati tahun ini adalah jumlah pelanggan telepon tetap (fixed line) PT. Telkom sebanyak 7,2 
juta pelanggan. Di akhir tahun 2001, industri seluler melayani 6,57 juta pemakai telepon seluler".

Penggunaan telepon seluler di era globalisasi saat ini, dapat dilihat sebagai suatu kebutuhan yang sangat penting. Gaya hidup going mobile ini, dimana orang ingin menghubungi dan dihubungi di manapun berada, menyebabkan telepon seluler menjadi alat yang wajib untuk dimiliki dan dibawa kemana saja oleh setiap orang. Peningkatan pemilikan atas telepon seluier memperlihatkan bahwa alat yang digunakan dalam proses komunikasi sekunder ini, selain merupakan barang mewah juga merupakan barang wajib untuk dimiliki.

Dalam ilmu komunikasi proses komunikasi sekunder diartikan sebagai proses penyampaian pesan oleh seseorang kepada orang lain dengan menggunakan alat atau sarana sebagai media kedua setelah memakai lambang sebagai media pertama. Alat atau sarana sebagai media kedua terdiri dari surat, telepon, teleks, surat kabar, majalah, radio, televisi, film dan lain-lain. (Effendy; 1984). Selanjutnya dijelaskan bahwa penyampaian pesan oleh seseorang kepada orang lain dengan menggunakan media pertama yang dimaksud adalah pengertian dari proses komunikasi primer. Lambang sebagai media primer dalam proses komunikasi adalah bahasa, isyarat, gambar, warna dan lain-lain. (Effendy; 1994).

Sebelum menguraikan tentang bagaimana tindak pidana penipuan menurut Kitab Undang-Undang Hukum Pidana dan bagaimana modus kejahatan penipuan dengan menggunakan Telepon Seluler, periu kiranya diuraikan terlebih dahulu pengertian Teknologi dalam Undang-undang Nomor 18 Tahun 2002.

Tentang Sistem Nasional Penelitian, Pengembangan, dan Penerapan IImu
Pengetahuan dan Teknologi yang selanjutnya disebut sebagai Undang-Undang IPTEK pasal 1 angka 2 Teknologi didefinisikan adalah cara atau metode serta proses atau produk yang dihasilkan dari penerapan dan pemanfaatan berbagai disiplin ilmu pengetahuan yang menghasilkan nilai bagi pemenuhan kebutuhan, kelangsungan, dan peningkatan mutu kehidupan manusia.

Dari rumusan pengertian yang ditegaskan dalam pasal 1 angka 2 Undang-Undang nomor 18 Tahun 2002 ini terlihat bahwa teknologi merupakan hasil yang diperoleh dari penerapan dan pemanfaatan berbagai disiplin ilmu pengetahuan untuk pemenuhan kebutuhan manusia. Selanjutnya dalam pasal 1 angka 1 Undang-undang ini, ditegaskan tentang pengertian IImu pengetahuan adalah rangkaian pengetahuan yang digali, disusun, dan dikembangkan secara sistematis dengan menggunakan pendekatan tertentu yang dilandasi oleh metodologi ilmiah, baik yang bersifat kuantitatif, kualitatif, maupun eksploratif untuk menerangkan pembuktian gejala alam dan / atau gejala kemasyarakatan tertentu.

Dalam hubungan dengan penulisan ini, diuraikan pula pengertian tentang Telekomunikasi. Dalam Undang-Undang Nomor 36 Tahun 1999 tentang. Telekomunikasi ditegaskan dalam pasal 1 angka 1 tentang pengertian telekomunikasi,yaitu setiap pemancaran, pengiriman dan / atau penerimaan dari setiap informasi dalam bentuk tanda-tanda, isyarat, tulisan, gambar, suara, dan bunyi melalui sistem kawat, optik, radio atau sistem elektromagnetik lainnya.

Selanjutnya dalam pasal 1 angka 2 Undang-Undang Nomor 39 Tahun 1999 ditegaskan pengertian Alat Telekomunikasi adalah setiap alat perlengkapan yang digunakan dalam bertelekomunikasi. Dalam pasal 1 angka 4 disebutkan Sarana dan 
Prasarana Telekomunikasi adalah segala sesuatu yang memungkinkan dan mendukung berfungsinya telekomunikasi.

Dari beberapa ketentuan yang terdapat di dalam Undang-Undang Nomor 18 Tahun 2002 tentang IPTEK terdapat keterkaitan dengan telepon seluler, sehingga dapatiah dikatakan bahwa telepon seluler merupakan produk yang dihasilkan dari penerapan berbagai disiplin ilmu pengetahuan yang menghasilkan nilai bagi pemenuhan kebutuhan, kelangsungan, dan peningkatan mutu kehidupan manusia. Sedangkan Undangundang Nomor 39 Tahun 1999 tentang Telekomunikasi dalam pasal 1 angka 2 jika dihubungkan dengan telepon seluler maka dapat dikatakan bahwa telepon seluler, merupakan salah satu alat telekomunikasi.

Telekomunikasi merupakan salah satu media manusia berinteraksi, dalam hal ini interaksi yang dilakukan dalam jarak jauh. Telekomunikasi perlu mendapatkan pengertian tersendiri karena memiliki karakteristik tersendiri pula. Ketika dua orang saling berinteraksi tetapi berada di luar jangkauan pandang, maka boleh dikatakan mereka ber-"telekomunikasi". Oleh karena itu bertelekomunikasi pasti melibatkan alat bantu seperti, radio, telepon, dan dengan perkembangan teknologi yang pesat sekarang ini, internet. Berkomunikasi baik antara individu dengan individu, individu dengan sekelompok individu lain, maupun sekelompok individu yang satu dengan yang lainnya, pada masa sekarang ini intensitasnya sangat tinggi.

Seiring dengan meningkatnya kebutuhan masyarakat untuk menggunakan telepon seluler sebagai alat komunikasi penting selain memberikan dampak positif, juga memberikan dampak negatif. Dampak negatif tersebut yaitu dengan munculnya modus kejahatan baru di era teknologi informasi dengan menggunakan media telepon seluler berupa penipuan dengan menggunakan Short Message Service (SMS). Peningkatan tindak kejahatan penipuan dengan menggunakan telepon seluler ini, disebabkan karena para pelaku menganggap bahwa kejahatan yang mereka lakukan itu tidak akan diketahui oleh orang lain, baik korban maupun pihak kepolisian. Hal tersebut terungkap dalam pengakuan para pelaku yang telah ditangkap oleh pihak kepolisian. Sehubungan dengan itu para pelaku kejahatan penipuan dengan modus operandi mengirimkan SMS inj, belum ada satupun kasusnya diputuskan oleh pengadilan untuk mernperoleh kekuatan hukum yang tetap.

Bagi kita yang mempunyai telepon seluler mungkin pernah menerima SMS serupa yang berisi tentang pemberitahuan bahwa kita telah mendapat undian dari salah satu perusahaan yang bergerak di bidang jasa telekomunikasi, seperti PT. Satelindo, PT. Telkomsel, atau Pro XL. Dari SMS tersebut jika kita belum mengetahui tentang modus kejahatan ini pasti kita akan merasa terkejut dengan disertai perasaan gembira dan langsung menuruti apa yang ada dalam SMS itu, sehingga kita menjadi korban berikutnya.

Yang menjadi pertanyaan, apakah kejahatan penipuan ini dapat dikategorikan sebagai tindak pidana penipuan, sebagaimana yang diatur dalam KUHPidana. Pertanyaan selanjutnya adalah bagajmanakah modus operandi dari penipuan dengan menggunakan medja telepon seluler melalui Short Message Service (SMS) itu. Pentingnya bahasan terhadap masalah ini agar hukum pidana dapat diterapkan untuk menjerat pelaku kejahatan penipuan menggunakan media telepon seluler dengan mengirimkan Short Message Service (SMS) 
agar supaya kejahatan ini dapat segera diberantas. Mengingat bahwa kejahatan penipuan dengan menggunakan telepon seluler ini belum ada satupun kasusnya telah memperoleh kekuatan hukum yang tetap oleh Pengadilan.

Dalam kamus umum bahasa indonesia istilah penipuan berasal dari kata tipu yang berarti perbuatan atau perkataan yang tidak jujur (bohong, palsu) dengan maksud menyesatkan, mengakali atau mencari untung; kecoh. Sedangkan dalam Hukum Pidana Penipuan merupakan salah satu tindak pidana yang pengaturannya dapat dijumpai dalam KUHPidana. Penga-turan tersebut terdapat dalam pasal 378 - 395. Dalam sistematika KUHPidana yang terdiri dari 3 (tiga) bagian yaitu,

$\begin{array}{ll}\text { Buku Kesatu } & \text { : Ketentuan Umum } \\ \text { Buku Kedua } & \text { : Kejahatan } \\ \text { Buku Ketiga } & \text { : Pelanggaran }\end{array}$

Tindak kejahatan ini terdapat dalam Buku kedua bab XXV yang mengatur tentang penipuan.

Dari sistematika KUHPidana di atas dapat dilihat bahwa tindak penipuan digolongkan sebagai kejahatan dan bukan pelanggaran. Mengenai istilah kejahatan dan pelanggaran dikatakan bahwa : "Kata-kata "kejahatan" dan "pelanggaran" kini merupakan istilahistilah sebagai terjemahan dari istilahistilah misdrijf dan overtreding dalam bahasa Belanda. Misdrijf atau "kejahatan" berarti suatu perbuatan yang tercela dan berhubungan dengan hukum, berarti tidak lain daripada "perbuatan melanggar hukum". "Overtreding" atau "pelanggaran" berarti suatu perbuatan yang melanggar sesuatu, dan berhubungan dengan hukum, berarti tidak lain daripada "perbuatan melanggar hukum". Jadi sebenamya arti kata dari kedua istilah itu sama, maka dari arti kata tidak dapat dilihat perbedaan antara kedua golongan tindak pidana ini." (Projdodikoro; 1986) Pendapat di atas dapat dilihat bahwa terdapat kesulitan untuk membedakan antara kejahatan dan pelanggaran karena kedua istilah ini terdapat arti yang sama yaitu "perbuatan melanggar hukum". Untuk membedakan kedua istilah ini, para sarjana Belanda mengemukakan dua cara untuk menemukan perbedaan tersebut. Seperti dikutip dalam buku yang ditulis oleh Prof. Dr. Wirjono Prodjodikoro, SH ditegaskan bahwa ada dua cara untuk menemukan perbedaan ini, yaitu pertama: secara meneliti maksud dari pembentuk undang-undang; dan kedua: secara meneliti sifat-sifat yang berbeda antara tindak-tindak pidana yang termuat dalam Buku II KUHPidana di satu pihak dan tindak-tindak pidana yang termuat dalam Buku III KUHPidana dilain pihak.(Prodjodikoro; 1986)

Menuruf M. v. T. pembagian atas dua jenis perbuatan pidana yaitu pelanggaran dan kejahatan didasarkan atas perbedaan prinsipil. Dikatakan bahwa kejahatan adalah "rechtsdeliten", yaitu perbuatan-perbuatan yang meskipun tidak ditentukan dalam undang-undang, sebagai perbuatan pidana, telah dirasakan sebagai onrecht, sebagai perbuatan yang bertentangan dengan tatahukum. Pelanggaran sebaliknya adalah "wetsdeliktern", yaitu perbuatan-perbuatan yang sifat melawan hukumnya baru dapat diketahui setelah ada wet yang menentukan demikian. Dari perbedaan yang dikemukakan di atas dapat dilihat bahwa penipuan merupakan salah satu tindak pidana yang terdapat ancaman pidananya dalam undangundang dan digolongkan ke dalam buku kedua tentang kejahatan (Moeljatno; 1983). 
Penipuan dengan Menggunakan Telepon Seluler Ditinjau dari KUHP; Theodorus J.B.R

Dalam KUHPidana pasal 378 dirumuskan bahwa "Barangsiapa dengan maksud untuk menguntungkan dirinya sendiri atau orang lain secara melawan hukum, dengan mempergunakan sebuah nama palsu atau suatu sifat palsu, dengan mempergunakan tipu muslihat ataupun dengan mempergunakan susunan kata-kata bohong, menggerakkan seseorang untuk menyerahkan sesuatu benda, untuk mengadakan perjanjian hutang ataupun untuk meniadakan piutang, karena salah telah melakukan penipuan, dihukum dengan hukuman penjara selama-lamanya empat tahun."

Dari rumușan pasal di atas dapat dilihat bahwa suatu tindakan dapat disebut sebagai tindak pidana penipuan apabila telah memenuhi unsur-unsur seperti di bawah ini:

\section{Maksud Untuk Menguntungkan Secara Melawan Hak}

Perkataan "dengan maksud" di dalam pasal ini adalah terjemahan dari perkataan "met het oogmerk", dan ini berarti bahwa opzet di dalam pasal ini haruslah ditafsirkan sebagai "opzet dalam arti sempit" atau semata-mata sebagai "opzet als oogmerk ", sehingga maksud dari si pelaku itu tidaklah boleh ditafsirkan lain kecuali "dengan maksud menguntungkan dirinya sendiri atau orang lain secara melawan hukum".

Mengenai perkataan di atas dapat dilihat dengan adanya putusan HOGE $R A A D$ dan Mahkamah Agung Indonesia (H.R. 27 Mei 1935, NJ 1936, Sl, W. 12944) yang memutuskan bahwa " si pelaku haruslah mempunyai maksud untuk menguntungkan diri sendiri atau menguntungkan orang lain secara melawan hak dan tidak perlu bahwa perbuatan tersebut telah menyebabkan timbulnya kerugian bagi orang lain. Hakim tidak periu memastikan siapa yang telah dirugikan." Selanjutnya dikatakan bahwa sifat dari penipuan sebagai kejahatan penjpuan terletak pada cara yang telah dipergunakan oleh si pelaku untuk meng-gerakkan orang lain agar orang lain tersebut menyerahkan sesuatu.

\section{Mempergunakan Nama Palsu atau Sifat Palsu}

Nama palsu itu haruslah berupa nama orang, ia dapat merupakan nama yang bukan nama sendiri dari si pelaku atau sebuah nama yang tak seorangpun yang mempergunakannya ataupun namanya sendiri akan tetapi yang tidak diketahui oleh umum. Sebagai contoh, nama "Saimin" dikatakan "Zaimin" itu bukan menyebut nama palsu, akan tetapi kalau ditulis, itu dianggap sebagai menyebut nama palsu (Soesilo, 1988).

"Sifat palsu", dapat dijelaskan dengan adanya putusan HOGE RAAD (H.R. 27 Maret 1893, W. 6327), yang memutuskan bahwa "Sifat palsu yang dipergunakan itu dapat berupa suatu sifat dengan mana seseorang telah bertindak secara palsu di depan orang lain, misalnya sebagai seorang kuasa, seorang perwakilan, seorang wali atau seorang pengampu dan dapat pula berupa sifat untuk mendapatkan kepercayaan, misalnya sebagai seorang pedagang, seorang pegawainegeri dan sebagainya."

\section{Tipu Muslihat}

Tipu muslihat adalah terjemahan dari perkataan "listige kunstgrepen", yaitu tindakan-tindakan yang demikian rupa sehingga menimbulkan kepercayaan atau memberikan kesan kepada orang yang digerakkan seolah-olah keadaannya adalah sesuai dengan kebenaran. Dalam hal ini tidaklah perlu bahwa tipu muslihat itu harus terdiri dari beberapa perbuatan, melainkan dengan suatu perbuatan tunggalpun sudah 
cukup untuk mengatakan bahwa di situ telah dipakai suatu tipu muslihat. Dapat dikatakan pula bahwa tipu muslihat harus dilakukan pelaku dengan sedemikian rupa liciknya, sehingga seorang yang berpikiran normal pun dapat tertipu.

Dari penjelasan di atas dapat diberikan contoh misainya seseorang telah datang ke sebuah rumah dengan mengatakan kepada pembantu rumah tangga dirumah tersebut, bahwa ia telah disuruh untuk mengambil sebuah pesawat televisi oleh majikannya untuk diperbaiki di bengkel, padahal semuanya itu adalah tidak benar dan karena tipu muslihatnya itu ia telah berhasil menggerakkan orang lain untuk menyerahkan sebuah pesawat televisi yang ingin dimiliki secara melawan hak.

\section{Susunan Kata-Kata Bohong}

Pada bagian ini dijelaskan bahwa perkataan "Susunan Kata-kata bohong" di dalam pasal ini adalah terjemahan dari perkataan "samenweefsel van verdichtsels", sehingga perbuatan seseorang dalam hal ini haruslah terjalin demikian rupa, sehingga kata-kata itu mempunyai hubungan antara satu dengan yang lainnya dan menimbulkan kesan bahwa kata-kata yang satu itu membenarkan kata-kata yang lain atau dengan perkataan lain bahwa susunan kata bohong harus lebih dari satu kata dan mempunyai hubungan satu dengan lainnya.

Hal yang perlu diperhatikan pula bahwa dalam menentukan kata-kata bohong tergantung pada tingkat kecerdasan setiap orang ataupun calon korban dalam menerima kata-kata bohong dari pelaku atau dengan perkataan lain bahwa oleh karena dalam kenyataannya bahwa tingkat kecerdasan orang itu berbeda antara satu dengan lainnya, sehingga mudah tidaknya seseorang digerakkan untuk berbuat sesuatu oleh orang lain dengan mempergunakan "susun-an kata-kata bohong" itu berbeda antara satu dengan yang lain tergantung pada tingkat kecerdasannya. Haruslah diselidiki terlebih dahulu apakah orang yang digerakkan itu mengetahui bahwa daya upaya yang dipergunakan oleh orang yang lain itu bertentangan dengan kebenaran ataupun tidak. Jika dapat dibuktikan, bahwa orang yang digerakkan itu sebenarnya memahami bahwa kata-kata yang dipergunakan oleh orang lain tersebut adalah kata-kata bohong, maka di dalam hal ini tidaklah terdapat "samenweefsel van verdichtsels".

Kriteria yang dipakai untuk mengukur tingkat kecerdasan seseorang itu adalah dengan mengukur menurut kecerdasan orang-orang ke dalam golongan mana orang yang tertipu itu termasuk.

\section{Menggerakkan Orang Untuk Menyerahkan Suatu Benda}

Untuk menjelaskan bagian ini, perlu dilihat unsur-unsur penipuan yang telah diuraikan terlebih dahulu. Dengan kata lain untuk menentukan bahwa bagian ini merupakan salah satu unsur penipuan haruslah dikaitkan dengan unsur yang lain. Unsur yang dimaksud misalnya "maksud menguntungkan diri sendiri atau orang lain secara melawan hak".

Keterkaitan antara unsur "menggerakkan orang" dapat dilihat dalam putusan HOGE RAAD (H. R. 29 April 1935. 1936 No. 50. W. 12965.) yang menegaskan bahwa : "apabila perbuatan menggerakkan orang lain untuk menyerahkan sejumlah uang tertentu itu adalah untuk tujuan tertentu, akan tetapi kemudian ternyata bahwa uang tersebut telah dipergunakan bukan untuk tujuan tersebut melainkan 
untuk kepentingan diri sendiri, maka si pelaku telah menguntungkan diri sendiri secara melawan hak, juga apabila ia telah meminta jumlah yang sama atau lebih besar jumlahnya dari orang yang menyerahkan uang itu".

Dari rumusan di atas dapat dilihat bahwa perbuatan menggerakkan orang lain untuk menyerahkan sejumlah uang, harus diikuti oleh maksud untuk menguntungkan diri sendiri secara melawan hak, dengan kata lain bila unsur "menggerakkan" dan "menyerahkan" di atas tidak dapat disebut sebagai unsur dari penipuan bila tidak terdapat unsur menguntungkan diri secara melawan hak.

Pada bagian ini pula di jelaskan bahwa untuk adanya "penyerahan" adalah perlu bahwa benda tersebut telah terlepas dari kekuasaan seseorang. Artinya bahwa benda itu telah berada pada kekuasaan orang lain. Mengenai pengertian benda dalam pasal ini dapat dilihat dalam penjelasan pada Pasal 362 KUHPidana. "sesuatu barang" diartikan sama dengan segala sesuatu yang berwujud termasuk pula binatang (manusia tidak masuk), misalnya, uang, baju, kalung dan sebagainya.Dalam pengertian barang masuk pula "daya listrik" dan "gas", meskipun tidak berwujud, akan tetapi dialirkan di kawat atau pipa. Barang itu tidak perlu mempunyai harga ekonomis (Soesilo, 1988).

Menyangkut "benda" atau "barang", terdapat perbedaan dalam pemberian hukuman terhadap tindak pidana penipuan ini, jika barang yang dimaksud bukan hewan, harga barang, utang atau piutang yang tidak lebih dari Rp. 250,-- Mengenai maksud ini, terdapat dalam rumusan Pasal $379 \mathrm{KUH}$ Pidana yang rumusannya berbunyi " Perbuatan yang diterangkan dalam Pasal 378 , jika barang yang diberikan itu bukan hewan, dan harga barang, utang atau piutang itu tidak lebih dari Rp. 250,-dihukum karena penipuan ringan, dengan hukuman penjara selama-lamanya tiga bulan atau denda sebanyak-banyaknya Rp. 900,-".

\section{Menggerakkan Orang Untuk Mengadakan Perjanjian Hutang}

Dalam putusan HOGE RAAD bahwa Hutang yang dimaksud dalam bagian ini adalah "perjanjian", misalnya untuk menyetorkan uang jaminan. Selanjutnya disebutkan dalam putusan HOGE RAAD yang berbunyi "perbuatan menggerakkan orang lain untuk membuat suatu perjanjian hutang dengan mempergunakan salah satu upaya penipuan juga mengandung maksud untuk menguntungkan diri sendiri atau orang lain secara melawan hak". (H. R. 28 Nop. 1921, N.J. 1922, 184, W. 10847; 20 Jan. 1913, NJ 1913. 504, W. 9453).

Dalam KUHPerdata Pasal 1313 disebutkan "Suatu perjanjian adalah suatu perbuatan dengan mana satu orang atau lebih mengikatkan dirinya terhadap satu orang lain atau Jebih". Selanjutnya dalam Pasal 1320 dijelaskan tentang syarat-syarat sahnya suatu perjanjian yang harus memenuhi 4 (empat) syarat yaitu:

1. sepakat mereka yang mengikatkan dirinya;

2. kecakapan untuk membuat suatu perikatan;

3. suatu hal tertentu;

4. suatu sebab yang halal.

Dari Pasal 1313 dan Pasal 1320 KUHI'erdata dapat dikaitkan dengan pasa1378 KUHPidana khususnya dalam unsur "menggerakkan orang untuk mengadakan perjanjian hutang", yang memberikan arti bahwa pelaku penipuan ini, dengan segala tipu muslihatnya mengge- 
rakkan orang lain (korban) atau pihak ketiga untuk mengadakan suatu perjanjian hutang berdasarkan unsur-unsur dalam Pasal 1320 ataupun meniadakan piutang, sehingga dengan sendirinya orang yang digerakkannya mengalami kerugian dan pelaku ataupun pihak ketiga memperoleh keuntungan secara melawan hukum.

Dalam Pasal 379a KUHPidana juga memberikan ancaman hukuman bagi pelaku yang menjadikan tindak penipuan sebagai mata pencahariannya atau kebiasaan yang rumusannya berbunyi "Barangsiapa membuat pencahariannya atau kebiasaannya membeli barang-barang dengan maksud supaya ia sendiri atau orang lain mendapat barang-barang itu dengan tidak melunaskan sama sekali pembayarannya, dihukum penjara selama-lamanya empat tahun.

Kejahatan ini, dalam ilmu Pengetahuan Hukum Pidana di sebut sebagai "Flessentrekkerij ". Perkataan "maksud" di dalam pasal ini adalah terjemahan dari perkataan "met het oogmerk", sehingga opzet di dalam pasal ini harus ditafsirkan sebagai opzet dalam arti sempit atau semata-mata sebagai opzet als oogmerk. Ini berarti bahwa harus dibuktikan, bahwa si pelaku itu adalah semata-mata "tanpa membayar lunas harga barang-barang yang dibelinya dan ingin menguasai barang-barang tersebut bagi dirinya atau orang lain.

Untuk membedakan antara "menjadikan sebagai mata pencaharian" dengan "menjadikan sebagai kebiasaan", dikatakan Drs. P.A.F. Lamintang, SH., bahwa "menjadikan sebagai kebiasaan" itu, perbuatannya harus sedikit-dikitnya terdiri dari dua perbuatan, sedangkan "menjadikan sebagai mata pencaharian" perbuatannya tidak mutlak harus. (Lamintang dan Samosir, 1979)
Setelah membahas tentang unsurunsur penipuan dalam KUHPidana, selanjutnya pada bagian ini penulis ingin menjelaskan tentang modus kejahatan penipuan dengan menggunakan telepon seluler dengan mengaitkannya dengan unsur-unsur penipuan dalam KUHPidana. Dari penjelasan ini akan ditarik kesimpulan bahwa penipuan dengan menggunakan telepon seluler dapat dikatakan sebagai tindak pidana penipuan.

Teknologi informasi saat ini, selain memberi dampak positif juga memungkinkan memberi dampak negatif bagi masyarakat pengguna hasil perkembangan teknologi itu. Dampak positif dapat dilihat bahwa dengan adanya perkembangan teknologi di bidang informasi dengan diciptakannya telepon seluler dimana manusia dapat mengirim dan menerima informasi kapan dan dimanapun berada baik dengan cara berkomunikasi secara sekunder (mengadakan pembicaraan) maupun hanya dengan menggunakan komunikasi primer (pesan tertulis / SMS) dapat memberikan berbagai kemudahan-kemudahan diantaranya biaya murah, cepat, tepat dan efisien.

Dampak negatif dapat dilihat salah satunya adalah bentuk kejahatan dengan modus operandi mengirimkan pesan singkat (Short Message Service/SMS) atau menghubungi calon korban secara langsung dengan menggunakan telepon seluler. Selain itu pula dapat dilihat bahwa kejahatan menggunakan media telepon tetap (fixed line) dan telepon seluler akhir-akhir ini tidak hanya penipuan melainkan apa yang sering didengar masyarakat yaitu teror. Bentuk kejahatan teror ini pula dapat berbentuk ancaman bom terhadap fasilitas-fasilitas publik (seperti pusat perbelanjaan, hotel, gedung pemerintah dII), ataupun bentuk 
ancaman terhadap pribadi atau kelompok dari seseorang yang tidak dikenal.

Dari data Exelcom yang disampaikan pada pelaksanaan dialog tanggal 20 Agustus 2002 tentang penipuan melelui telepon seluler di Jakarta, yang menghadirkan ahli hukum komunikasi Hinca IP. Panjaitan, Kepala Dinas Penerangan Polda Metro Jaya Anton Bachrul Alam, General Manager Customer Service Exelcom Wardhani Soedjono dan Dyah Tari dari Yayasan Lembaga Konsumen Indonesia (YLKI) terungkap pada periode Januari 2002 sampai dengan Juli 2002 terdapat 3.000 pengguna telepon seluler yang mengadukan aksi penipuan. Umumnya pengguna telepon seluler itu nyaris menjadi korban. ( $h h(p: / / w w w$ kompas com/compas $\% 2 D$ cetak/0208/24/nasiona/ raky06. htm)

Andi Hamzah dalam bukunya yang berjudul Hukum Pidana yang Berkaitan dengan Komputer menegaskan bahwa kecanggihan teknologi, dewasa ini tidaklah semata-mata berkisar di sekitar kecanggihan peralatan komputer saja, akan tetapi mencakup pula alat yang diotomatisasikan seperti di bidang telekomunikasi (telepon otomatis), otomatisasikan di bidang perbankan (misalnya memasukkan mata uang ke dalam kotak, dan sebagainya) (Hamzah, 1993).

Penulis berpendapat bahwa jenis jenis kejahatan tersebut dilakukan dengan menggunakan media telepon tetap (fixed line) ataupun telepon seluler, karena para pelaku beranggapan bahwa orang yang diteror ataupun yang ditipu tidak akan mengetahui identitasnya secara akurat karena tidak bertatap muka secara lang-sung. Hal tersebut terungkap dalam penyidikan yang dilakukan oleh Tim Reserse dan Kriminal (Reskrim) Polda Metro Jaya yang mengintrogasi kelompok pelaku penipuan dengan modus operandi mengirim-kan pesan singkat/SMS kepada para korban seperti yang diberitakan dalam media massa Suara Merdeka edisi Rabu, 22 Januari 2003.

Tindak kejahatan penipuan ini, modus operandinya menggunakan 2 (dua) cara yaitu menghubungi dengan menelpon langsung calon korban dan mengirimkan pesan singkat / SMS melalui telepon seluler. Inti dari komunikasi langsung dan pesan singkat tersebut adalah memberitahukan bahwa korban mendapatkan undian dari salah satu perusahaan yang bergerak di bidang telekomunikasi seperti Telkomsel, Satelindo, Pro XL dll.

Pesan singkat atau berita yang disampaikan, selengkapnya berbunyi " Sim Card MENTARI anda saat ini, dalam status peraih GRAND PLUS Box point reward 2003 u/info : (08155265677) (08155248227). Layanan Interaktif Via Telepon. Pengirim : + SATELINDO" atau juga tertulis dalam SMS "Selamat Anda Memenangkan Hadiah undian Pro-XL, Hub:0818684377, 0818481791 , atau 0817134953 . Dari pesan tersebut pada menu kotak masuk pesan (message) akan menampilkan pengirim adalah nomor telepon seluler dari pelaku dan bukan nomor operator GSM seperti Satelindo, Pro.XL,, Telkomsel dan lain-lain.

Selain menggunakan pesan singkat, pelaku juga seringkali melakukan penipuan dengan cara meng-hubungi langsung melalui telepon seluler ke telepon tetap (fixed line) milik calon korban. Dalam pembicaraan biasanya pelaku seakan-akan memberitahukan bahwa korban telah memenangkan undian yang diselenggarakan oleh salah satu perusahaan yang bergerak di bidang Telekomunikasi. Calon korbanpun diberitahukan nomor telepon seluler yang dapat dihubungi untuk pembicaraan selanjutnya dan nomor rekening pelaku. 
Untuk membuka nomor rekening di beberapa bank, para pelaku menggunakan Kartu Tanda Penduduk (KTP) palsu. KTP palsu yang dimaksud adalah KTP yang dibuat dengan menggunakan nama, alamat yang berbeda-beda. Dengan kata lain bahwa satu pelaku memiliki beberapa KTP dengan nama, alamat berbeda. Selanjutnya setelah pesan singkat ataupun berita yang dikirim oleh pelaku diterima oleh calon korban, kebanyakan para korban merasa penasaran disertai rasa gembira dan segera menghubungi kembali nomor telepon seluler yang mengirimkan atau menghubunginya. Dalam pembicaraan kembali pelaku mulai melakukan berbagai cara dengan bahasanya untuk menipu korban dengan mengatakan bahwa korban akan mendapatkan uang dengan jumlah yang banyak ataupun mendapatkan mobil kjang. Untuk memperoleh hadiah-hadiah yang dikatakan pelaku, korban harus mengirim sejumlah uang yang telah ditentukan dan apabila korban telah meyakinkan bahwa dirinya sebagai pemenang undian maka pelaku memberikan instruksi-instruksi selanjutnya.

Instruksi tersebut berupa perintah pelaku untuk meminta korban ke ATM dan membimbing secara langsung dengan katakata berbeda dari intruksi ATM melalui pembicaraan telepon seluler ataupun perintah untuk mentransfer uang secara langsung ke rekening pelaku. Instruksi secara langsung melalui telepon seluler itu terdiri atas perintah untuk mentransfer uang ke rekening pelaku. Akan tetapi korban seakan tidak tahu bahwa perintah tersebut akan merugikannya, karena para pelaku menggunakan berbagai macam cara untuk menipu korban. Kalimat-kalimat yang diperintahkan pelaku misalnya "ketiklah nilai nominal yang akan ditransfer". Korban pun langsung melaksanakan perintah itu, karena berpikir jumlah uang yang akan diketik masuk ke rekeningnya. Korban baru sadar setelah proses transfer selesai saat kertas saldo akhir rekening dikeluarkan mesin dan membaca kertas saldo yang berkurang sesuai jumlah uang yang baru ditransfernya.

Instruksi untuk mentransfer langsung melalui bank ke rekening pelaku hampir sama dengan instruksi menstransfer uang melaluj ATM Hanya perbedaannya apabila pelaku menginstruksikan untuk mentransfer uang ke rekening melauj ATM, pelaku tersebut membimbing secara langsung dan biasanya korban pun mempunyai telepon seluler sedangkan perintah untuk mentransfer uang ke rekening bank, pelaku hanya memberikan instruksi pada saat pembicaraan korban dengan pelaku dan biasanya cara ini dilakukan pelaku bagi korban yang dihubungi melalui telepon tetap (fixed line) tapi tidak menutup kemungkinan bagi korban yang memiliki telepon seluler.

Selain kedua modus kejahatan di atas, dapat dilihat juga modus kejahatan penipuan dengan menggunakan telepon seluler ini yang menghubungi langsung kepada kotban bahwa salah satu anggota keluarga sedang dalam keadaan sakit berat karena kecelakaan tabrak lari. Dari modus tersebut pelaku meminta agar supaya korban harus mentransfer sejumlah uang untuk pembayaran rumah sakit dan biaya pengobatan. Jika uangnya tidak segerah dikirimkan maka anggota keluarga yang dimaksud tidak akan tertolong nyawanya. Tentang modus kejahatan penipuan inj dapat dilihat dalam Kompas, 14 Mei 2000.

Dari beberapa bentuk kejahatan penipuan dengan modus operandi menggunakan telepon seluler yang dijelaskan di atas, penulis hendak mengaitkannya dengan tindak pidana penipuan sebagaimana yang diatur dalam 
Pasal 378 KUHPidana. Adapun penjelasannya seperti dibawah ini:

\section{Maksud Untuk Menguntungkan Secara Melawan Hak}

Dari cara pelaku memintah korban untuk mentransfer atau mengirimkan sejumlah uang melalui rekening pelaku yang sebelumnya telah didahului oleh berbagai kata-kata bohong dan tipu muslihat melalui pesan singkat dan kemudian korban pun segera mentransfer atau mengirimkan sejumlah uang sesuai permintaan pelaku.

Dapat dilihat bahwa perkataan "dengan maksud" dalam pasal ini yang merupakan terjemahan dari perkataan " met het oogmerk" dan opzet harus ditafsirkan dalam arti sempit atau semata-mata sebagai "opzet als oogmerk ", sehingga maksud pelaku itu harus ditafsirkan "dengan maksud menguntungkan diri sendiri atau orang lain secara melawan hukum". Dengan demikian unsur pertama dalam Pasal 378 KUHPidana telah terpenuhi.

\section{Mempergunakan Nama Palsu atau Sifat Palsu}

Dengan menggunakan nama palsu seperti Budi Santoso, Wirahadiwijaya, Marzuki alias Juki alias Bambang Sudarsono, Sultan Abidin alias Latang menunjukkan para pelaku menggunakan beberapa nama yang berbeda satu sama lainnya sehingga dapat dikatakan sebagai nama palsu sebagaimana yang diatur dalam pasal ini. Dan untuk lebih meyakinkan, para pelaku membuat beberapa Kartu Tanda Penduduk (KTP), dengan nama yang berbeda-beda untuk dipergunakan dalam membuka nomor rekening bank yang berbeda satu dengan lainnya.
Dengan bertindak sebagai salah satu operator GSM, sebagai seorang dokter dari Rumah Sakit Pusat Pertamina (RSPP) dan seorang polisi dapat dilihat bahwa para pelaku dalam melakukan penipuan telah bertindak secara palsu kepada orang lain, sehingga tindakan tersebut dapat dikatakan sebagai sifat palsu dan telah memenuhi unsur kedua dari tindak pidana penipuan.

\section{Tipu Muslihat}

Dengan mengirimkan pesan singkat/ SMS melalui telepon seluler atau pun mengadakan komunikasi langsung dengan memberitahukan bahwa korban adalah salah satu pemenang undian yang diselenggarakan oleh salah satu perusahaan yang bergerak di bidang Telekomunikasi dan pelaku seolah-olah memberikan kesan kepada korban bahwa keadaan seperti itu sesuai dengan kebenarannya. Dengan demikian, dapat dikatakan bahwa pelaku dengan tindakan-tindakannya telah melakukan tipu muslihat sebagaimana diatur dalam pasal ini.

\section{Susunan Kata-Kata Bohong}

Dengan mengirimkan Pesan Singkat melalui telepon seluler ataupun mengadakan komunikasi langsung dengan memberitahukan bahwa Sim Card Mentari anda saat ini, dalam status peraih Grand Plus Box point reward 2003 untuk info (08155265677), (08155248227). Layanan Interaktif Via Telepon. Pengirim : + SATELINDO., atau tertulis pesan "Selamat Anda Memenangkan Hadiah undian Pro-XL, Hub: 0818684377 , 0818481791,08187134953 atau dengan menghubungi langsung dengan mengabarkan dari kantor polisi dan mengatakan bahwa salah satu anggota keluarga menjadi korban tabrak lari dan kini berada di ruang gawat darurat Rumah Sakit Pertamina 
Pusat. Selanjutnya ada yang mengaku bahwa dirinya sebagai seorang dokter di RSPP dan mengabarkan bahwa kondisi salah seorang anggota keluarga berada dalam kondisi kritis di ruang gawat darurat sehingga salah satu anggota tubuhnya hanus diamputasi dan memerlukan biaya sebesar Rp 10.250.000,.

Beberapa pesan maupun kabar di atas dapat dilihat bahwa para pelaku telah menggunakan susunan kata-kata bohong yang mempunyai hubungan antara satu dengan yang lainnya dan menimbulkan kesan seakan-akan bahwa kata-kata yang satu itu membenarkan kata-kata yang lain atau dengan perkataan lain bahwa susunan kata bohong harus lebih dari satu kata dan mempunyai hubungan satu dengan lainnya.

\section{Menggerakkan Orang Lain Untuk Menyerahkan Suatu Benda}

Dengan cara menggunakan tipu muslihat dan susunan kata-kata bohong yang disampaikan melalaui telepon seluler baik dengan menggunakan pesan singkat (Short Message Service/SMS) maupun menghubungi langsung kepada korban, sehingga korban merasa penasaran disertai rasa gembira sehingga langsung menghubungi kembali pelaku diikuti dengan tindakan untuk mentransfer uang melalui ATM ataupun ke rekening pelaku berdasarkan instruksinya dan korban baru sadar ketika uang yang ditransfer telah berpindah kerekening pelaku dapat di katakan bahwa uang tersebut telah berada dalam kekuasaannya.

Dari tindakan yang dilakukan oleh pelaku yang mengakibatkan tergeraknya korban untuk mentransfer uang tersebut, maka dapat dikatakan bahwa perbuatan pelaku menggerakkan orang lain untuk menyerahkan sejumlah uang tertentu itu adalah untuk tujuan tertentu, akan tetapi kemudian ternyata bahwa uang tersebut talah dipergunakan bukan untuk tujuan tersebut melainkan untuk kepentingan diri sendiri secara melawan hak. Oleh karenanya tindakan itu dapat dikatakan sebagai unsur dalam pasal ini.

Dengan terpenuhinya unsur-unsur penipuan dalam penjelasan di atas dapat dikatakan bahwa penipuan dengan menggunakan telepon seluler merupakan salah satu kejahatan yang terdapat ancamannya di dalam Pasal 378 - 395 KUHPidana yang mengatur tentang tindak pidana penipuan. Pembahasan di atas, melalui penulisan ini dapat dikemukakan beberapa saran baik bagi masyarakat pengguna telepon seluler, pihak perusahaan, kepolisian dan pihakpihak yang secara langsung maupun tidak langsung berhubungan dengan teknologi telepon seluler ini, yaitu:

1. Tindak pidana penipuan dengan menggunakan telepon seluler ini merupakan salah satu modus kejahatan baru di era informasi dan teknologi saat ini, dan telah mengakibatkan banyak korban. Dengan demikian fungsi dan tujuan diciptakannya teknologi telepon seluler setidaktidaknya telah mengalami pergeseran akibat dari tindak kejahatan ini.Asas dan tujuan diselenggarakannya Telekomunikasipun seakan mengalami suatu pergeseran karena sebagaimana yang diatur dalam pasal UndangUndang Nomor 36 Tahun 1999 bahwa Telekomunikasi diselenggara-kan berdasarkan asas manfaat, adil dan merata, kepastian hukum, keamanan, kemitraan, etika, dan kepercayaan pada diri sendiri selanjutnya dalam pasal 3 ditegaskan bahwa Teleko- 
munikasi diselenggarakan dengan tujuan untuk mendukung persatuan dan kesatuan bangsa, meningkatkan kesejahteraan dan kemakmuran rakyat secara adil dan merata, mendukung kehidupan ekonomi dan kegiatan pemerintahan, serta meningkatkan hubungan antarbangsa. Oleh karenanya perlu diadakan pengaturan lebih khusus mengenai kejahatan ini dengan membuat suatu peraturan perundangundangan yang khusus mengatur tentang ancaman hukuman bagi kejahatan-kejahatan di bidang telekomunikasi mengingat ancaman hukuman 4 (empat) tahun yang terdapat dalam Pasal 378 KUHPidana tidak sebanding dengan perbuatan pelaku yang merugikan para korban.

2. Bagi para pengguna telepon seluler diharapkan agar supaya teliti terhadap modus kejahatan ini. Apabila menerima pesan tersebut hendaknya jangan langsung terpengaruh oleh besarnya hadiah yang akan diperoleh karena hal itu merupakan penipuan dan segeralah mengadukannya kepada Polri sebagai pihak yang berwajib dalam menangani kejahatan ini. kepada pihak penegak hukum hendaknya lebih pro aktif dalam menangani kejahatan ini. Kepada perusahaan yang bergerak dibidang telekomunikasi telepon seluler hendaknya perlu mengatur pendataan administratif terhadap setiap kartu pra bayar dari pengguna telepon seluler agar lebih memudahkan peniyidjk dalam menemukan nomor kartu pra bayar telepon seluler yang diduga digunakan untuk melakukan tindak pidana penipuan.

Penulisan ini menggunakan metode deskriptif normatif dengan pendekatan studi kepustakaan baik bidang hukum pidana materil, hukum pidana yang berkaitan dengan komputer, teknologi dan internet, Kriminologi, hukum perdata, dan literatur tentang Sistem Telekomunikasi di Indonesia.

\section{Daftar Pustaka}

Anonimous, Undang-Undang Nomor. 36 Tahun 1999 tentang Telekomunikasi. 2000. Jakarta: Sinar Grafika.

Anonimous, Undang-Undang Nomor. 18 Tahun 2002 tentang Sistem Nasional Penelitian, Pengembangan, Dan Penerapan Ilmu Pengetahuan Dan Teknologi (IPTEK), 2002. Bandung:Citra Umbara.

Effendy, Onóng Uchjana. 1984./lmu Komunikasi Teori dan Praktek. Bandung:Remaja Rosdakarya.

Hamzah, Andi. 1994. Asas-Asas Hukum Pidana (Edisi Revisi), Jakar-ta: Rineka Cipta.

1993. Hukum Pidana Yang Berkaitan Dengan Konaputer (Edisi Kedua), Jakarta :Sinar Grafika.

hhtp://www kompas com/kompas\%2D cetak/02Q8/24/nasional/-aky06.htm

Lamintang, P.A.F. dan Samosir, C. Djisman. 1979. Hukurn Pidana Indonesia, Bandung:Sinar Baru.

Moeljatno.1983. Asas-Asas Hukum Pidana, Jakarta:Rineka Cipta.

Silalahi, Nurain.2002. Layanan In, formasi dan Teleko-munikasi Mobil Nirkabel, Jakarta: Elex Media Komputindo. 
Soesilo, 1988. Kitab Undang-Undang Hukum Pidana (KUHP) Serta Komentar- komentarnya Lengkap

Pasal Demi Pasal,

Sukabumi;Politeia Bogor.

$\square \square \square$ 